\title{
Keterampilan Pemecahan Masalah Peserta Didik: Studi Kasus di SMA Negeri 1 Wonomulyo
}

\author{
Muhiddin Palennari ${ }^{1 *}$, Lasmi $^{1}$, Rachmawaty $^{1}$ \\ ${ }^{1}$ Jurusan Biologi, Fakultas Matematika dan Ilmu Pengetahuan Alam, Universitas Negeri Makassar, \\ Indonesia
}

*Email: muhiddin.p@unm.ac.id

\begin{tabular}{|c|c|}
\hline Info Artikel & Abstrak \\
\hline $\begin{array}{l}\text { Diterima: } 5 \text { April } 2021 \\
\text { Direvisi: } 15 \text { Oktober } 2021 \\
\text { Diterima } \\
\text { untuk diterbitkan: } 27 \\
\text { Oktober } 2021\end{array}$ & $\begin{array}{l}\text { Penelitian ini merupakan jenis penelitian deskriptif dengan pendekatan } \\
\text { kuantitatif. Masalah dalam penelitian ini terkait dengan pemberdayaan } \\
\text { keterampilan pemecahan masalah. Beberapa hasil penelitian } \\
\text { mengungkapkan bahwa keterampilan pemecahan masalah siswa masih } \\
\text { rendah, padahal hampir di seluruh sekolah saat ini telah dituntut untuk }\end{array}$ \\
\hline $\begin{array}{l}\text { Keywords: } \\
\text { Keterampilan Pemecahan } \\
\text { Masalah, Pembelajaran } \\
\text { Biologi, SMA Negeri } 1 \\
\text { Wonomulyo }\end{array}$ & $\begin{array}{l}\text { menerapkan kurikulum } 2013 \text { yang diharapkan mampu memusatkan } \\
\text { pembelajaran kepada siswa untuk mengembangkan kemampuannya. } \\
\text { Penelitian ini bertujuan untuk mendeskripsikan keterampilan pemecahan } \\
\text { masalah siswa SMA Negeri } 1 \text { Wonomulyo pada mata pelajaran biologi. } \\
\text { Subjek penelitian dalam penelitian ini adalah satu kelas dari siswa kelas } \\
\text { XII IPA yang berjumlah } 32 \text { orang. Pengumpulan data pada penelitian ini } \\
\text { menggunakan soal tes keterampilan pemecahan masalah berbentuk uraian } \\
\text { dan wawancara semi terstruktur bersama guru mata pelajaran biologi } \\
\text { beserta beberapa orang siswa yang bertujuan untuk dijadikan sebagai } \\
\text { informasi tambahan untuk mendukung hasil penelitian. Data hasil } \\
\text { penelitian dianalisis menggunakan analisis statistik deskriptif untuk } \\
\text { mendeskripsikan keterampilan pemecahan masalah siswa, serta analisis } \\
\text { menggunakan program excel untuk menghitung rata-rata tiap indikator } \\
\text { keterampilan pemecahan masalah. Hasil penelitian menunjukkan bahwa } \\
\text { keempat indikator keterampilan pemecahan masalah berada pada kategori } \\
\text { baik yaitu dengan persentase merumuskan masalah } 66,80 \% \text {; } \\
\text { mengembangkan jawaban sementara (hipotesis) } 75,39 \% \text {; merencanakan } \\
\text { solusi } 76,95 \% \text {; dan mengecek kembali/membuat kesimpulan } 73,83 \% \text {. } \\
\text { Secara keseluruhan keterampilan pemecahan masalah siswa SMA Negeri } \\
\text { 1 Wonomulvo berada pada kategori baik dengan rata-rata } 73.24 \text {. }\end{array}$ \\
\hline
\end{tabular}

(C) 2021 Universitas Bengkulu. This is an open-access article under the CC-BY license (https://creativecommons.org/licenses/by/4.0)

\section{PENDAHULUAN}

Abad ke-21 disebut sebagai abad pengetahuan, abad ekonomi berbasis pengetahuan, abad teknologi informasi, globalisasi, revolusi industri 4.0, dan sebagainya (Redhana, 2019). Abad yang dikenal semua orang sebagai abad pengetahuan yang merupakan landasan utama untuk berbagai aspek kehidupan (Kurnia, 2015). Berbagai organisasi mencoba merumuskan berbagai macam 
kompetensi dan keterampilan yang diperlukan dalam menghadapi abad ke-21 (Zubaidah, 2016). Sugiyarti, Arif, \& Mursalin, (2018) menyatakan bahwa di sekolah formal, pembelajaran sudah dituntut untuk menerapkan kemampuan 4C (Critical Thinking, Communication, Collaboration, Creativity). Critical thinking (berpikir kritis) yaitu kemampuan siswa dalam berpikir kritis berupa menalar, mengungkapkan, menganalisis, dan menyelesaikan masalah. As the massive advencement in $21^{\text {st }}$ century, the role of education is to prepare generations in mastering the skills they need to face challengs arised in their era (Husamah, Fatmawati, \& Setyawan, 2018).

The curriculum is like a compass in guiding the ship to sail the world of education. Like a compass, curriculum plays an important role in organizing, directing, and guiding the learning activities (Rumahlatu, Hulisalen, \& Takaria, 2016). Kurikulum 2013 diyakini sebagai kebijakan strategis dalam menyiapkan dan menghadapi tantangan, serta tuntutan masyarakat Indonesia masa depan (Machali, 2014). Program pembelajaran menggunakan kurikulum 2013 menuntut perubahan mindset pada diri guru agar lebih mengaktifkan peserta didik dengan menerapkan pendekatan saintifik, yang tujuannya untuk meningkatkan kemampuan berpikir tingkat tinggi, seperti menganalisis, membandingkan, menalar, mengasosiasi, dan menyimpulkan (Bwefar, Hala, \& Palennari, 2019). Teachers have had to teach according to the specific curriculum mandates of each region (Ahmad, 2014).

Namun dalam implementasi kurikulum 2013, masih terdapat beberapa kendala utamanya dari guru. Sebagian besar guru belum dapat menerapkan kurikulum 2013 sebagaimana mestinya (Krissandi \& Rusmawan, 2015). Sehingga siswa mengalami masalah berpikir utamanya pemecahan masalah. Karena salah satu tuntutan kurikulum 2013 sesuai dengan tujuan pembelajaran biologi yang dipaparkan oleh Karmana (2014), bahwa tujuan pembelajaran biologi di SMA harus mampu mengembangkan potensi siswa sehingga memiliki kemampuan pemecahan maalah. Karena kendala tersebut, sehingga menyebabkan beberapa hasil penelitian mengungkapkan bahwa keterampilan pemecahan masalah siswa masih dalam kategori rendah atau kurang. Seperti yang diungkapkan oleh hasil penelitian Mustofa dan Rusdiana (2016); Purnamasari dan Sugiman (2015); dan juga disimpulkan Karmana, (2014) dalam penelitiannya bahwa kemampuan pemecahan masalah biologi siswa masih berkategori kurang. Hal ini juga diperkuat oleh laporan Programme for International Student Assesment (PISA) yang melaporkan bahwa kemampuan pemecahan masalah siswa Indonesia masih tergolong rendah dibandingkan dengan negara anggota lainnya (Ilmi, 2019).

Padahal beberapa penelitian telah mengungkapkan berbagai solusi pembelajaran untuk meningkatkan keterampilan pemecahan masalah dalam suatu inovasi model pembelajaran, seperti pada penelitian oleh Destalia, Suratno \& Aprilia, (2014) yang menyimpulkan bahwa penerapan model PBM dengan metode eksperimen dapat meningkatkan keterampilan pemecahan masalah siswa pada mata pelajaran biologi. Tambunan (2019) stated that problem solving strategies were more effective than scientific approaches to students problem solving abilities. Penelitian Palennari (2012) juga memaparkan salah satu contoh pembelajaran melalui PBL yakni strategi interaksi PBL dan Jigsaw membuat mahasiswa dapat berpikir lebih banyak untuk mengembangkan kemampuan menganalisis, mengeksplorasi, dan menginferensi permasalahan yang sedang mereka bahas. Penelitian Palennari (2016) bahwa sintaks keempat pada strategi PBL Jigsaw mengarahkan siswa melakukan kerja sama untuk mencari penyelesaian masalah dalam suasana kooperatif. Palennari (2018) menyatakan bahwa fase akhir PBL, pebelajar akan menyadari dirinya sendiri kalau mereka sudah belajar dalam memecahkan situasi masalah nyata.

Siswa yang memiliki keterampilan pemecahan masalah mampu mengaplikasikan pengetahuan yang mereka miliki dalam konteks permasalahan yang mereka hadapi (Agustini, Subagia, Wayan \& Suardana, 2015). Pemecahan masalah sangat sesuai jika diterapkan pada proses pembelajaran, karena pemecahan masalah tidak hanya mengharapkan siswa sekedar mendengarkan, mencatat, kemudian menghafal materi pelajaran, akan tetapi melalui pemecahan masalah, siswa menjadi aktif berpikir, menerima informasi, berkomunikasi, mencari dan mengolah data, dan akhirnya menyimpulkan (Desliana, Amelia \& Putri, 2018). 
Pembelajaran biologi diransang untuk dapat merumuskan permasalahan, mencari solusi atas suatu masalah, menemukan fakta pendukung sampai akhirnya menyimpulkan permasalahan, disini diperlukan keterampilan berpikir yang melahirkan ide baru sebagai pemecahan masalah masalah (Listiana, 2011). Hasil keterampilan pemecahan masalah perlu diukur untuk mengetahui bagaimana dari pemberian inovasi-inovasi metode pembelajaran yang dilakukan. Keterampilan pemecahan masalah juga perlu diukur dalam tujuan mengetahui bagaimana kesiapan siswa dalam menghadapi tantangan abad 21 (Hidayat et al., 2017).

Berdasarkan penjelasan di atas, maka disimpulkan bahwa berbagai tuntutan dalam kurikulum 2013 yang mengharapkan guru menerapkan kegiatan pembelajaran yang berpusat pada siswa. Kemampuan pemecahan masalah begitu penting sehingga analisis kemampuan pemecahan masalah pada tingkat SMA/MA perlu dikaji sejak dini (Hanifa, Akbar, \& Abdullah, 2019). Pembelajaran biologi sangat erat kaitannya dengan pemecahan masalah termasuk yang berkaitan dengan kehidupan sehari-hari. Sejalan dengan penjelasan diatas, maka penelitian ini bertujuan untuk mengetahui keterampilan pemecahan masalah siswa SMA Negeri 1 Wonomulyo pada mata pelajaran biologi.

\section{METODE}

Penelitian ini menggunakan jenis penelitian deskriptif pendekatan kuantitatif. Bersifat deskriptif karena peneliti harus mendeskripsikan gambaran tentang keterampilan pemecahan masalah siswa SMA Negeri 1 Wonomulyo. Desain penelitian menggunakan desain penelitian deskriptif dengan metode penelitian deskriptif pendekatan kuantitatif. Subjek penelitian dalam penelitian ini adalah diambil satu kelas dari kelas XII IPA di SMA Negeri 1 Wonomulyo. Variabel penelitian adalah keterampilan pemecahan masalah (problem solving skills). Instrumen penelitian yang digunakan adalah menggunakan tes keterampilan pemecahan masalah yang terdiri dari 8 butir soal uraian serta pedoman wawancara guru dan siswa untuk mendukung hasil penelitian.

Teknik analisis data yaitu analisis data dilakukan dengan menggunakan SPSS (Statistical Package for Social Science) statistics 22. Keterampilan pemecahan masalah siswa dianalisis dengan analisis statistik deskriptif yang meliputi rata-rata, kemudian disajikan dalam bentuk tabel dengan memperhatikan kategori. Untuk mengetahui tingkat ketercapaian keterampilan pemecahan masalah siswa maka dihitung dengan menggunakan rumus:

$$
\text { Nilai }=\frac{\text { Jumlah skor yang diperoleh }}{\text { Jumlah skor maksimum }} \times 100
$$

Sumber: (Yuanari, 2011).

Hasil dari perhitungan nilai keterampilan pemecahan masalah siswa kemudian dikonversikan ke dalam kategori keterampilan pemecahan masalah menurut Bwefar (2019), kategori penggolongan keterampilan pemecahan masalah berdasarkan Depdiknas (2008). Persentase rata-rata tiap indikator keterampilan pemecahan masalah dihitung menggunakan rumus (Purwanto, 2013) dalam (Hanifa, Akbar, \& Abdullah, 2019) berikut.

$$
\mathrm{NP}=\frac{R}{S M} \times 100 \%
$$

Sumber: (Hanifa, Akbar \& Abdullah, 2019).

Keterangan:

$\mathrm{NP}$ : nilai persen yang dicari

$\mathrm{R}$ : skor mentah yang diperoleh siswa

SM : skor maksimum

100 : bilangan tetap 


\section{HASIL DAN PEMBAHASAN}

Distribusi frekuensi dan persentase kategori tiap indikator keterampilan pemecahan masalah siswa bertujuan untuk menggambarkan persentase setiap kategori pada indikator keterampilan pemecahan masalah. Distribusi frekuensi dan persentase dapat dilihat pada tabel 1.

\section{Tabel 1}

Distribusi Frekuensi dan Persentase Kategori Tiap Indikator Keterampilan Pemecahan Masalah Siswa SMA Negeri 1 Wonomulyo Pada Mata Pelajaran Biologi

\begin{tabular}{|c|c|c|c|c|c|c|c|c|c|}
\hline \multirow[t]{2}{*}{ Kategori } & \multirow[t]{2}{*}{$\mathbf{J}$} & \multicolumn{2}{|c|}{$\begin{array}{l}\text { Merumuskan } \\
\text { Masalah }\end{array}$} & \multicolumn{2}{|c|}{$\begin{array}{c}\text { Mengembangkan } \\
\text { Jawaban Sementara } \\
\text { (Hipotesis) }\end{array}$} & \multicolumn{2}{|c|}{$\begin{array}{l}\text { Merencanakan } \\
\text { Solusi }\end{array}$} & \multicolumn{2}{|c|}{$\begin{array}{c}\text { Mengecek } \\
\text { Kembali/Membuat } \\
\text { Kesimpulan }\end{array}$} \\
\hline & & $\mathbf{F}$ & $\mathbf{P}(\%)$ & $\mathbf{F}$ & $\mathbf{P}(\%)$ & $\mathbf{F}$ & $\mathbf{P}(\%)$ & $\mathbf{F}$ & $\mathbf{P}(\%)$ \\
\hline Sangat Baik & 32 & 9 & 28,13 & 12 & 37,5 & 15 & 46,87 & 12 & 37,5 \\
\hline Baik & 32 & 14 & 43,75 & 17 & 53,12 & 11 & 34,38 & 16 & 50 \\
\hline Cukup & 32 & 2 & 6,25 & 2 & 6,25 & 6 & 18,75 & 3 & 9,37 \\
\hline Kurang & 32 & 7 & 21,87 & 1 & 3,13 & 0 & 0,00 & 1 & 3,13 \\
\hline $\begin{array}{l}\text { Sangat } \\
\text { Kurang }\end{array}$ & 32 & 0 & 0,00 & 0 & 0,00 & 0 & 0,00 & 0 & 0,00 \\
\hline Rata-rata & & & 66,80 & & 75,39 & & 76,95 & & 73,83 \\
\hline
\end{tabular}

Tabel 1 menunjukkan bahwa sebagian besar keterampilan pemecahan masalah siswa dalam kategori baik pada indikator merumuskan masalah yakni mencapai 43,75 \%. Keterampilan pemecahan masalah siswa pada indikator mengembangkan jawaban sementara (hipotesis) sebagian besar berada pada kategori baik, yaitu sekitar 53,12 \%. Keterampilan pemecahan masalah siswa pada indikator merencanakan solusi didominasi oleh kategori sangat baik, yaitu 46,87\% dan kategori baik, yaitu 34,38 \%. Keterampilan pemecahan masalah siswa pada indikator mengecek kembali/ membuat kesimpulan didominasi oleh kategori baik, yaitu $50 \%$.

Tiap indikator keterampilan pemecahan masalah memiliki rata-rata yang berada pada kategori baik. Hal ini menunjukkan bahwa sebagian besar keterampilan pemecahan masalah siswa berada pada kategori baik. Tabel rata-rata tiap indikator dapat dilihat pada tabel 2.

\section{Tabel 2}

Rata-rata Tiap Indikator Keterampilan Pemecahan Masalah

\begin{tabular}{lcc}
\hline Indikator Keterampilan Pemecahan Masalah & Rata-rata & Kategori \\
\hline Merumuskan Masalah & 66,80 & Baik \\
Mengembangkan jawaban sementara (hipotesis) & 75,39 & Baik \\
Merencanakan solusi & 76,95 & Baik \\
Mengecek kembali/membuat kesimpulan & 73,83 & Baik \\
\hline
\end{tabular}

Tabel 2 di atas menggambarkan rata-rata keempat indikator keterampilan pemecahan masalah berada pada kategori baik. Rata-rata tertinggi berada pada indikator merencanakan solusi, kemudian disusul oleh indikator mengembangkan jawaban sementara (hipotesis), indikator mengecek kembali/membuat kesimpulan, dan terakhir indikator merumuskan masalah.

Data hasil analisis statistik deskriptif keterampilan pemecahan masalah siswa SMA Negeri 1 Wonomulyo pada mata pelajaran biologi setelah dianalisis menggunakan program SPSS (Statistical Package for Social Science) hasilnya dapat dilihat pada tabel 3.

Tabel 3 menggambarkan atau mendeskripsikan bahwa data yang telah diperoleh dari 32 orang siswa sebagai subjek penelitian memiliki rata-rata nilai keterampilan pemecahan masalah siswa yaitu 73,24. Adapun nilai minimum dari keterampilan pemecahan masalah siswa yaitu 43,75. Nilai maksimum dari keterampilan pemecahan masalah siswa yaitu sebesar 93,75. Median pada nilai keterampilan pemecahan masalah siswa yaitu 73,44 dan range atau selisih dari nilai maksimum dengan nilai minimum yaitu sebesar 50,00. 
Tabel 3

Deskripsi Nilai Keterampilan Pemecahan Masalah Siswa SMA Negeri 1 Wonomulyo Pada Mata Pelajaran Biologi

\begin{tabular}{lc}
\hline Statistik Deskriptif & Keterampilan Pemecahan Masalah \\
\hline Standar Deviasi & 11,96 \\
Rata-rata & 73,24 \\
Nilai Minimum & 43,75 \\
Nilai Maksimum & 93,75 \\
Median & 73,44 \\
Range & 50,00 \\
\hline Jumlah Sampel & 32 \\
\hline
\end{tabular}

Distribusi frekuensi dan presentase kategori keterampilan pemecahan masalah menggambarkan frekuensi dan persentase dari masing-masing kategori dalam keterampilan pemecahan masalah. Distribusi frekuensi dan persentase kategori keterampilan pemecahan masalah dapat dilihat pada tabel 4 .

\section{Tabel 4}

Distribusi Frekuensi dan Persentase Kategori Keterampilan Pemecahan Masalah siswa SMA Negeri 1 Wonomulyo Pada Mata Pelajaran Biologi

\begin{tabular}{lccc}
\hline Kategori & Jumlah & Frekuensi & Persentase \% \\
\hline Sangat Baik & 32 & 11 & 34,37 \\
Baik & 32 & 16 & 50 \\
Cukup & 32 & 5 & 15,63 \\
Kurang & 32 & 0 & 0 \\
Sangat Kurang & 32 & 0 & 0 \\
\hline
\end{tabular}

Tabel 4 di atas menunjukkan bahwa tingkat keterampilan pemecahan masalah siswa SMA Negeri 1 Wonomulyo pada mata pelajaran biologi berada pada kategori baik, dibuktikan dengan persentase yang cukup besar dibandingkan dengan kategori lain, yaitu sebesar $50 \%$ dari 32 orang siswa. Sebelas orang lainnya berada pada kategori kurang dan lima orang lainnya berada pada kategori sedang. Serta tidak ada siswa yang berada pada kategori kurang maupun sangat kurang.

Secara keseluruhan, keterampilan pemecahan masalah siswa SMA Negeri 1 Wonomulyo pada mata pelajaran biologi berada pada kategori baik dengan rata-rata 73,24. Hal tersebut disebabkan oleh beberapa faktor. Berdasarkan dengan guru bahwa di sekolah tersebut telah menggunakan kurikulum 2013 sebagaimana yang seharusnya digunakan dalam sistem pendidikan Indonesia saat ini. Lebih lanjut, dipaparkan guru bahwa perangkat pembelajaran yang digunakan oleh guru pada mata pelajaran biologi telah mencakup pemecahan masalah. Model pembelajaran yang digunakan yaitu model discovery learning. Diperkuat oleh penelitian (Deswita, Fauzan dan Yerizon (2018) bahwa berdasarkan hasil penelitian yang telah dilakukan, maka dapat disimpulkan bahwa penerapan model pembelajaran penemuan terbimbing (guided discovery learning) dapat meningkatkan aktivitas dan pemahaman konsep dan kemampuan pemecahan masalah siswa. Several previous studies revealed that it is true that this learning model has been applied by several previous studies and shows an increase in problem-solving skills such as in research Nahdi (2018); Tanjung, Syahputra and Irvan (2020); Supratinah, Budiyono and Subanti (2015); (Effendi, (2012); Simanjuntak, Napitupulu, Manullang, Manalu and Sinambela (2018); dan Adelia dan Surya (2017).

Beberapa faktor lain berikut yang menyebabkan keterampilan pemecahan masalah siswa berada pada kategori baik, di antaranya metode diskusi dan praktikum dinilai memberikan dampak positif dalam proses pembelajaran. Hasil penelitian Indriastuti, Herlina dan Widiyaningrum (2013) mengungkapkan bahwa sebagian besar siswa menguasai dengan baik kemampuan menemukan permasalahan saat praktikum. Hasil wawancara guru dan siswa menyatakan bahwa selama proses pembelajaran, sebagian besar siswa mampu memecahkan masalah terhadap permasalahan yang disajikan. Hal ini karena siswa sering dipertemukan dengan masalah-masalah yang menyangkut 
lingkungan sekitar atau kehidupan nyata. Pernyataan ini juga dibuktikan oleh rencana pelaksanaan pembelajaran yang digunakan guru bahwa salah satu sumber belajar yang digunakan adalah lingkungan setempat.

Guru juga menyampaikan bahwa salah satu strategi yang digunakan untuk meningkatkan keterampilan pemecahan masalah siswa adalah melengkapi sarana dan prasarana. Hal tersebut dinilai penting, sebagaimana dijelaskan Megasari (2014) bahwa suksesnya pembelajaran di sekolah didukung oleh pendayagunaan sarana dan prasarana pendidikan yang ada di sekolah secara efektif dan efisien. Pernyataan ini juga didukung oleh Emda (2017) yang menyatakan bahwa sarana laboratorium dapat menjadi sumber belajar untuk memecahkan berbagai masalah melalui kegiatan praktik/praktikum, baik itu masalah dalam pembelajaran maupun masalah yang terjadi di tengah masyarakat yang membutuhkan penanganan dengan uji laboratorium. Further explained that "The science curriculum should be revisited and should be made to include activities and exercise that would cater for the learning differences of the students (Udeani \& Adeyemo, 2011).

Faktor utama yang menyebabkan keterampilan pemecahan masalah siswa berada pada kategori baik adalah karena siswa telah dibiasakan dalam memecahkan masalah selama proses pembelajaran. Sehingga membiasakan siswa untuk aktif menemukan pengetahuan dan pengalamannya sendiri dengan tetap dibimbing oleh guru. Hal ini sesuai dengan kondisi bahwa agar siswa bisa terlatih maka harus dilatih terus-menerus atau diberikan stimulus secara terusmenerus maka siswa akan memberikan respon. Sebagaimana dijelaskan dalam teori belajar bahwa siapa yang menguasai stimulus-respons sebanyak-banyaknya ialah orang yang pandai. Pembentukan stimulus-respons dilakukan melalui ulangan-ulangan atau berulang-ulang. Seperti yang dikemukakan oleh Thorndike bahwa salah satu prinsip belajar adalah law of exercise bahwa belajar akan berhasil apabila banyak latihan serta mengulang apa yang didapat. Berdasarkan hasil percobaan yang dilakukan oleh Ivan Pavlov (1849-1936) menghasilkan kesimpulan bahwa beberapa hal yang perlu diperhatikan dalam belajar, antara lain ialah bahwa dalam belajar perlu adanya kebiasaan-kebiasaan yang telah melekat pada diri dapat mempengaruhi proses belajar yang bersifat skill (Abdurakhman \& Rusli, 2015). Suryawati (2013) menyatakan bahwa pengalaman siswa dalam kegiatan belajar, sikap, kemahiran, dan pengetahuan dapat digabungkan untuk memecahkan masalah yang dihadapi.

Setelah menyimak pembahasan di atas, maka dapat dikatakan bahwa keterampilan pemecahan masalah siswa SMA Negeri 1 Wonomulyo pada mata pelajaran biologi berada pada kategori baik. Namun hal tersebut masih perlu ditingkatkan hingga mencapai kategori sangat baik. Kategori tersebut dapat dicapai dengan meningkatkan proses pembelajaran dan tetap membiasakan siswa dalam pemecahan masalah.

\section{KESIMPULAN}

Berdasarkan hasil penelitian yang telah dilaksanakan, maka dapat disimpulkan bahwa keterampilan pemecahan masalah siswa SMA Negeri 1 Wonomulyo pada mata pelajaran biologi berada pada kategori baik dengan rata-rata 73,24. Adapun persentase tiap kategori dari keterampilan pemecahan masalah yaitu 34,37 kategori sangat baik, $50 \%$ kategori baik, dan 15,65 $\%$ kategori cukup. Saran untuk peneliti selanjutnya agar dalam melakukan penelitian keterampilan pemecahan masalah yang mencakup lebih banyak indikator keterampilan pemecahan masalah sehingga hasil yang diperoleh dapat lebih maksimal.

\section{DAFTAR PUSTAKA}

Abdurakhman, O., \& Rusli, R.K. (2015). Teori belajar dan pembelajaran inovatif (pp. 1-28).

Adelia, W.S., \& Surya, E. (2017). Resolution to increase capacity by using math students learning guided discovery learning (gdl). International Journal of Sciences: Basic and Applied Research (IJSBAR)., 34(1), 144-154.

Agustini, D., Subagia, I wayan, \& Suardana, I. (2015). Pengaruh Model Pembelajaran Sains 
Teknologi Pelajaran IPA di Mts Negeri Patas. Jurnal Media Pendidikan Matematika, 3(2), $100-108$.

Ahmad, D. (2014). Understanding the 2013 curriculum of english teaching through the teachers' and policymakers' perspectives. International Journal of Enhanced Research in Educational Development, 2(4), 6-15.

Bwefar, M. I., Hala, Y., \& Palennari, M. (2019). Pembentukkan Keterampilan Pemecahan Masalah Biologi Melalui Penerapan Model Problem Based Learning (PBL). Prosiding Seminar Nasional Biologi VI, 382-392.

Destalia, L., Suratno, \& Aprilya, S. (2014). Peningkatan Keterampilan Pemecahan Masalah Dan Hasil Belajar Melalui Penerapan Pembelajaran Berbasis Masalah (PBM) Dengan Metode Eksperimen Pada Materi Pencemaran Lingkungan. Pancaran, 3(4), 213-224.

Deswita, L., Fauzan, A., \& Yerizon. (2018). Increased Activity, Ability To Understand Concepts And Mathematical Problem Solving Through Guided Discovery Learning Models Of Class VII. 2 Of SMP Negeri 15 Sijunjung Academic Year 2017/2018. International Journal of Progressive Sciences and Technologies (IJPSAT) ISSN: 2509-0119, 101-107.

Effendi, L. A. (2012). Pembelajaran Matematika Dengan Metode Penemuan Terbimbing Untuk Meningkatkan Kemampuan Representasi dan Pemecahan Masalah Matematis Siswa SMP. Jurnal Penelitian Pendidikan, 13(2), 1-10.

Emda, A. (2017). Laboratorium Sebagai Sarana Pembelajaran Kimia Dalam Meningkatkan Pengetahuan dan Keterampilan Kerja Ilmiah. Lantanida Journal, 5(1), 84-92.

Hanifa, N. I., Akbar, B., \& Abdullah, S. (2019). Analisis Kemampuan Kemecahan Masalah Siswa Kelas X IPA Pada Materi Perubahan Lingkungan dan Faktor Yang Mempengaruhinya. Jurnal Penelitian Pendidikan Biologi, 2(2), 121-128.

Hidayat, S. R., Setyadin, A. H., Hermawan, H., Kaniawati, I., Suhendi, E., Siahaan, P., \& Samsudin, A. (2017). Pengembangan Instrumen Tes Keterampilan Pemecahan Masalah Pada Materi Getaran, Gelombang, dan Bunyi. Jurnal Penelitian \& Pengembangan Pendidikan Fisika, 3(2), 157-166.

Hidayat, W., \& Sariningsih, R. (2018). Kemampuan Pemecahan Masalah Matematis Dan Adversity Quotient Siswa SMP Melalui Pembelajaran Open Ended. Jurnal Nasional Pendidikan Matematika, 2(1), 109.

Husamah, Fatmawati, D., \& Setyawan, D. (2018). OIDDE Learning Model: Improving Higher Order Thinking Skills Of Biology Teacher Candidates. International Journal of Instruction, 11(2), 249-264.

Ilmi, A. R. M. (2019). Model Pembelajaran Creative Problem Solving (CPS) Untuk Meningkatkan Performa Pemecahan Masalah Siswa. Jurnal Rekayasa, Teknologi, dan Sains, 3(1), 34-41.

Indriastuti, Herlina, L., \& Widiyaningrum, P. (2013). Kesiapan Laboratorium Biologi dalam Menunjang Kegiatan Praktikum SMA Negeri di Kabupaten Brebes. Unnes Journal of Biology Education, 2(2), 2252-6579.

Karmana, I. W. (2014). Profil Kemampuan Pemecahan Masalah Biologi Siswa Sma Di Kota Mataram. Jurnal Ilmiah Biologi "Bioscientist", 2(1), 2338-5006. 
Kurnia, G. (2015). Pengembangan Alat Asesmen Keterampilan Menulis Menggunakan Teknologi Komputasi Awan Pada Sekolah Menengah Atas Di Kota Bandung. Jurnal Pendidikan Indonesia, 1-11.

Listiana, L. (2011). Pemberdayaan Keterampilan Berpikir Dalam Pembelajaran Biologi Melalui Model Kooperatif Tipe GI (Group Investigation) dan TTW (Think, Talk, Write). Seminar Nasional X Pendidikan Biologi FKIP UNS, 2, 1-7-069.

Machali, I. (2014). Kebijakan Perubahan Kurikulum 2013 Dalam Menyongsong Indonesia Emas Tahun 2045. Jurnal Pendidikan Islam, 3(1), 71.

Megasari, R. (2014). Peningkatan Pengelolaan Sarana dan Prasarana Pendidikan Untuk Meningkatkan Kualitas Pembelajaran di SMPN 5 Bukittinggi. Jurnal Administrasi Pendidikan, 2(1), 636-831.

Mustofa, M. H., \& Rusdiana, D. (2016). Profil Kemampuan Pemecahan Masalah Siswa Pada Pembelajaran Gerak Lurus. Jurnal Penelitian \& Pengembangan Pendidikan Fisika, 2(2), 1522.

Nahdi, D. S. (2018). Eksperimentasi Model Problem Based Learning dan Model Guided Discovery Learning Terhadap Kemampuan Pemecahan Masalah Matematis Ditinjau Dari Self Efficacy Siswa. Jurnal Cakrawala Pendas, 4(1). p-ISSN: 2442-7470; e-ISSN: 2579-4442.

Palennari, M. (2012). Potensi Integrasi Problem Based Learning Dengan Pembelajaran Kooperatif Jigsaw Dalam Meningkatkan Keterampilan Berpikir Kritis Mahasiswa. Jurnal Bionature, 13(1), 1-9.

Palennari, M. (2016). Pengaruh Pembelajaran Integrasi Problem Basic Learning Dan Kooperatif Jigsaw Terhadap Keterampilan Berpikir Kritis. Jurnal Ilmu Pendidikan Universitas Negeri Malang, 22(1), 111-468.

Palennari, M. (2018). Problem Based Learning (PBL) Memberdayakan Keterampilan Berpikir Kritis Pebelajar Pada Pembelajaran Biologi. In Seminar Nasional Biologi, 587-592.

Purnamasari, P. D., \& Sugiman. (2015). Analisis Kemampuan Pemecahan Masalah Matematika Siswa Kelas XI SMK Muhammadiyah I Patuk Pada Pokok Bahasan Peluang. Jurnal Pendidikan Matematika Dan Sains, 1-7.

Redhana, I. W. (2019). Mengembangkan Keterampilan Abad Ke-21 Dalam Pembelajaran Kimia. Jurnal Inovasi Pendidikan Kimia, 13(1).

Rumahlatu, D., Hulisalen K. E., \& Takaria, J. (2016). An analysis of the readiness and implementation of 2013 curriculum in the west part of seram district, maluku province, indonesia. International Journal of Enviromental \& Science Education, 11 (12), 5662-5675.

Sugiyarti, L., Arif, A., \& Mursalin. (2018). Pembelajaran abad 21 di SD. Prosiding Seminar Dan Diskusi Nasional Pendidikan Dasar 2018: Pembelajaran Abad 21, 439-444.

Supratinah, U., Budiyono, \& Subanti, S. (2015). Eksperimentasi Model Pembelajaran Discovery Learning, Problem Based Learning, dan Think Pair Share Dengan Pendekatan Saintifik. Jurnal Elektronik Pembelajaran Matematika, 3(10), 1138-1149.

Suryawati, E. (2013). Implementasi Pembelajaran Kontekstual Rangka Untuk Meningkatkan 
Keterampilan Proses Sains, Pemecahan Masalah, dan Penguasaan Konsep IPA. Jurnal Pendidikan dan Pembelajaran, 20 (2).

Tanjung, D. F., Syahputra, E., \& Irvan, I. (2020). Problem Based Learning, Discovery Learning, And Open Ended Models: An Experiment On Mathematical Problem Solving Ability. Jurnal Teori dan Aplikasi Matematika, 4(1), 9.

Tambunan, H. (2019). The Effectiveness Of The Problem Solving Strategy And The Scientific Approach To Students' Mathematical Capabilities In High Order Thinking Skills. International Electronic Journal of Mathematics Education, 14(2), 293-302.

Udeani, U., \& Adeyemo S. A. (2011). The Relationship Among Teachers' Problem Solving Abilities, Student's Learning Styles And Students' Achievement In Biology. International Journal of Educational research and technology, 2(1), 82-87.

Yuanari, N. (2011). Penerapan Strategi TTW (Think Talk Write) Sebagai Upaya Meningkatkan Kemampuan Pemecahan Masalah dan Disposisi Matematis Siswa Kelas VII SMPN 5 Wates Kulonprogo (skripsi dipublikasikan), Universitas Negeri Yogyakarta, Indoneisa.

Zubaidah, S. (2016). Keterampilan abad ke-21: keterampilan yang diajarkan melalui pembelajaran. 